\title{
Transcribing the Qur'an in Early Umayyad Times: The Codex Parisino-petropolitanus
}

The Codex Parisino-petropolitanus was found among Qur'anic fragments which were kept in the 'Amr mosque in Fustat until the end of the eighteenth and beginning of the nineteenth centuries when two French scholars, Jean-Joseph Marcel and Jean-Louis Asselin de Cherville, managed to buy a sizeable amount of leaves. ${ }^{1}$ The folios we know today are divided among four collections, which are, in order of size, the Bibliothèque Nationale de France in Paris (formerly Asselin de Cherville collection), ${ }^{2}$ the National Library of Russia in Saint Petersburg (formerly Marcel collection), the Biblioteca Apostolica Vaticana in the Vatican ${ }^{3}$ and the Nasser D. Khalili Collection of Islamic art in London. ${ }^{4}$ The ninety-eight parchment folios which I was able to trace (others may surface in the future) measure $33 \times 24 \mathrm{~cm}$ and contain roughly 45 percent of the Qur'anic text as we know it today. We can infer from these data that the original manuscript comprised between 210 and 220 folios, which means that some 17 to 18 square meters of parchment were required in order to produce this quarto volume of fair size. ${ }^{5}$ As the other hijäzi manuscripts, the Codex

1 See F. Déroche, La transmission écrite du Coran dans les débuts de l'islam. Le codex Parisinopetropolitanus, [Texts and studies on the Qurān 5] Leiden-Boston, 2009, pp. 10-13 and 14-16. The following chapter is based on the results of the research published in this book.

2 F. Déroche, Les manuscrits du Coran: Aux origines de la calligraphie coranique [Bibliothèque Nationale, Catalogue des manuscrits arabes, $2^{\mathrm{e}}$ partie, Manuscrits musulmans, I/1], Paris, 1983, pp. 59-6o, nos 2 and 3. A facsimile of the part of the Codex corresponding to f. ${ }^{1-56}$ has been published by F. Déroche and S. Noja Noseda, Le manuscrit Arabe 328 (a) de la Bibliothèque nationale de France [Sources de la transmission manuscrite du texte coranique I, Les manuscrits de style hijâzî, 1], Lesa, 1998. The study of the Saint Petersburg part of the manuscript allowed to determine that the f. $57-70$ of Paris, BnF Arabe 328 (described separately in the 1983 catalogue, as Arabe $328 \mathrm{~b}$ ) were actually part of the same codex (see F. Déroche, op. cit., p. 22). The manuscript can also be accessed on the Gallica website of the $\mathrm{BnF}$ (gallica.bnf.fr).

3 Vat. Ar. 1605/1, see G. Levi della Vida, Frammenti coranici in carattere cufico nella Biblioteca Vaticana, Vatican, 1947, p. IV, and 1-2, reproduced on pl. 1.

$4 \mathrm{KFQ}$ 6o, see F. Déroche, The Abbasid tradition, Qur'āns of the 8th to the 1oth centuries [The Nasser D. Khalili collection of Islamic art, I], London, 1992, p. 32 and pl. on p. 30.

5 F. Déroche, op. cit. (2009), p. 23. 
Parisino-petropolitanus is a codex, that is to say the dominant variety of book of the Late Antiquity. ${ }^{6}$ Its gatherings are quaternions with the sides of same kind facing each other-flesh facing flesh and hair facing hair. ${ }^{7}$ This does not mean that the gatherings were obtained by folding. Actually, some "accidents" interrupting the hair-flesh sides sequence (for instance f. 42 to 48 of the Parisian part of the manuscript) show that parchment bifolios equivalent to half a skin were stacked up one above the other and then folded. ${ }^{8}$ On the other hand, the chines are located in places which exclude any folding process in the production of the quires.

The text has been transcribed with long lines which are distributed over the whole page, leaving almost no margins-except on the inner side of the folio. This is not the result of later trimmings, which could have eliminated the margins. In many places, the natural edge of the skin has been preserved and coincides roughly with that of the folio. ${ }^{9}$ This way of using most of the available parchment surface was clearly the copyists' decision. It was not meant either to keep down the consumption of parchment as the average height of the script is rather important, probably because the copy was meant for public use. The traces of ruling which can be observed here and there concur with the preceding observations: the copyists prepared the transcription and the final appearance of the copy has been planned, although the number of lines varies from one page to the next. ${ }^{10}$

The script follows the custom of this period of not paying much attention to the spaces between the words and within a word when it contains letters which are not connected to each other. Actually, the groups of letters are scattered on the page in a rather regular way. A corollary of this way of handling the script is the possibility of dividing a word at the end of a line when needed - although words are never divided at the end of a page. The origin of this practice has probably to be traced down to the Late Antique tradition of scriptio continua. ${ }^{11}$

6 The epistle of 'Abd al-Masīh ibn Ishạa al-Kindī claims that the early Muslims left the text of the Qur'an in the form of leaves and rolls like the scrolls of the Jews, until the caliph 'Uthmān changed this practice. See P. Casanova, Mohammed et la fin du monde: étude critique sur l' islam primitif, Paris, 1911, p. 121; G. Troupeau, 'al-Kindì', $E I^{2}$, V, pp. 123-124.

$7 \quad$ F. Déroche et al., Islamic codicology. An introduction to the study of manuscripts in Arabic script, London, 2006, pp. $72-74$.

8 F. Déroche, op. cit. (2009), pp. 24-26.

9 See for instance Paris, BnF Arabe 328, f. 2, 5,6 or Saint Petersburg, NLR, Marcel 18, f. 1, 11 or 22.

10 Very often, the number of lines remains identical when there is a change of hand (see F. Déroche, op. cit., p. 28). In the manuscript, they vary from 21 to 28 lines to the page. Hands B, C and D tend to favour a lower number than A and E.

11 See W. Diem, Untersuchungen zur frühen Geschichte der arabischen Orthographie. IV. Die 
The most distinctive feature of the Codex Parisino-petropolitanus is the fact that it is the result of teamwork. Five copyists were involved in the transcription of the ninety-eight folios which I was able to trace. The way in which the work was distributed and even the actual number of copyists cannot be definitively established as half of the manuscript is lost.

The most important contributor to the copy of the text is Hand A (fig. 1) who produced seventy-three folios written with 21 to 28 lines to the page in a clear hijäzi script. ${ }^{12}$ He appears first in the manuscript, but he did not work continuously: in six occasions he left his place to a fellow copyist after completing a full recto side, although the verse he was transcribing did not stop at the end of the folio. The same rule was followed by three other scribes-a different situation is found with the fifth one, Hand C. As a result, there is no opening with two hands visible at the same time, one on the verso of a folio and another one on the recto of the next one. The script of Hand A is rather inelegant, but regular and legible. He mostly uses diacritical marks for the nūn (about 70 percent of the dots). Three horizontal rows of two elongated dots serve as a separation between the verses.

The second copyist by order of importance is Hand C (fig. 3). ${ }^{13}$ His contribution (sixteen folios) coincides with the end of what remains of the Codex Parisino-petropolitanus. Between 39: 55 and 41: 31, there is a gap separating the last folio in Hand A from the beginning of the portion in Hand C's script which does not include any contribution by another copyist. ${ }^{14}$ The number of lines varies from 21 to 25 , but it is most of the time either 22 or 23 . His script is crisp and regular, denoting some experience in the field of writing. Hand D indicates that professionals were included in the team, although this copyist does not seem to always have paid much attention to the work if we judge from the many mistakes and corrections found in his contribution. The diacritics are very infrequent and the verse endings are indicated by clusters of four elongated dots arranged in the shape of a square or less often set one above the other in a column.

The other three contributors, B, D and E, worked in close association with A who, from time to time, left them in charge of the transcription of two to

Schreibung der zusammenhängenden Rede. Zusammenfassung, Orientalia NS $5^{2}$ (1983), pp. $386-387$ (§242).

12 F. Déroche, op. cit. (2009), pp. 31-34.

13 Ibid., pp. 37-39.

14 These elements, as well as the impossibility to examine the back of the quires, explain why I decided to describe separately this contribution in the catalogue of the Bibliothèque Nationale (see above). 
fourteen pages before turning back to work. The interruptions are concentrated between 3:195 and 7:94. Hand B is the most important of the three in terms of their contribution (fig. 2). ${ }^{15} \mathrm{He}$ wrote the equivalent of seven folios distributed in three short sequences. His script is much sparser with fewer lines to the page (between 21 and 22) and slender letters: his alif height is ten times the width of the calamus instead of seven with Hand C and eight with A. ${ }^{16}$ Hand B mostly marks with diacritics the nūn, then the $b \bar{a}$. Two parallel columns of three elongated dots separate the verses.

Hands D and E appear as minor contributors to the common task-but, once again, the situation may have been different in the original state of the manuscript. Both wrote the two pages of an opening, in other words the equivalent of a folio. Hand D stands out as the most skilled copyist of the group, with a clearly professional script (fig. 4). ${ }^{17}$ The difference with Hand E is striking: the latter is obviously writing strenuously (fig. 5$)^{18}$

Throughout the manuscript, one notices how regularly the ends of the verses are indicated, even if Hand $\mathrm{C}$ seems sometimes to have been less rigorous. This contradicts the view expressed by Theodor Nöldeke who, on the basis of later evidence, considered that the division into verses was not a regular feature of the early transmission of the text. ${ }^{19}$ Each of the copyists has his own way of indicating this, but all rely on the same repertory: a cluster of oblong dots arranged in (a) column(s).

Although repeating four to six times the same movement of the hand in order to indicate the end of a verse was apparently done without problem by all the copyists, they were more reluctant when it came to adding diacritical dots to the rasm in order to distinguish homographs. The use of these dots was perfectly known as the manuscript contains a fair amount of them, but the gap between the Codex Parisino-petropolitanus and a modern edition is revealing: the comparison between a page of the Cairo edition with 9: 114-119 and the corresponding place on $\mathrm{f}$. 44a of the Parisian part of the manuscript shows that instead of 129 dots present today we only find five.

In addition to the scarcity of these dots, there exists a discrepancy between the various copyists regarding the use of diacritics. ${ }^{20}$ Hand $\mathrm{E}$ never uses

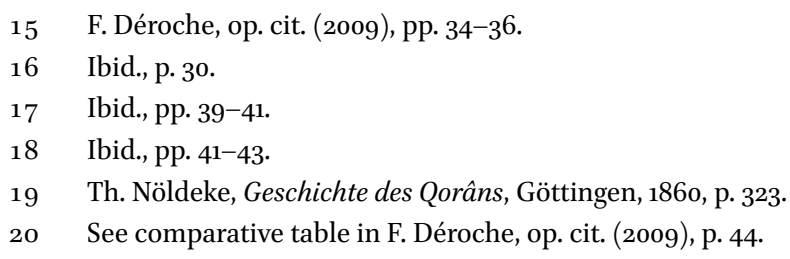


diacritics in the two pages he transcribed. Hand $\mathrm{C}$ does not fare much better: on the sixteen folios he wrote, he only marked dots in five instances. As a whole, the jim and $q \bar{a} f$ are never identified. Hands A and B are more frequently dotting the letters than the other contributors, but the former never writes diacritics below the line (for $b \vec{a}^{3}$ and $y \vec{a}^{3}$ ) and the latter never differentiates the $k h \bar{a}, d \bar{a} d, z \bar{a}$ and ghayn, although he marks more often than A the two and three dots for $t \bar{a}$ ' and $t h \bar{a}$. One could expect, according to what sources like al-Dānī say about the early use of diacritics, that $t \bar{a}^{\prime}$ and $y \vec{a}^{\prime}$ at the beginning of a verbal form were singled out by the copyists in order to give more clarity to the text. Such is not the case and these two consonants are rarely dotted. Hands $\mathrm{A}$ and $\mathrm{C}$ actually never differentiate $y \bar{a}$. Another point should also be stressed: in many instances, the use of diacritics by Hand A is somehow concentrated: the number of dots found in line 9 of the Parisian folio $2 b$ or in line 16 of the Saint Petersburg folio $1 b$ is far larger than in the rest of the folio. The short vowels and the notations of hamza, tashdid etc. are utterly absent.

In his study of the early Qur'anic manuscripts of the Asselin de Cherville collection, Michele Amari already noted that, in addition to the use of this very specific script, the hijazzi, the early handwritten transmission was typified by its orthography, which amounted, in his words, to "a merciless war against the alif". ${ }^{21}$ Régis Blachère spoke later of scriptio defectiva. ${ }^{22}$ This definition can remain in use if understood properly. The Arabic script is in itself defective as it does not note the short vowels. In the case of the scriptio defectiva found in early Qur'anic copies, the script fails to write correctly the $\mid \bar{a} /$ and is somewhat inconsistent in the way in which it writes $|\bar{l}|$ and in its use of diacritical marks - in addition to the lack of short vowels.

The Quranic orthography is one of the elements that have to be taken into account when studying the written transmission of the text during the Umayyad period. Amari had already noticed a number of situations in which there was a discrepancy with the modern use. ${ }^{23} \mathrm{~A}$ few problems remained to be solved. The first one was the "modern" point of comparison: Amari had been working with Hinckelmann's edition of the text, and I decided to rely for this work on the Cairo edition. It is not a scientific edition and we know

21 M. Amari, Bibliographie primitive du Coran ... Extrait de son mémoire inédit sur la chronologie et l'ancienne bibliographie du Coran, publié et annoté par Hartwig Derenbourg, in Centenario della nascita di Michele Amari I, Palermo, 1910, p. 20.

22 R. Blachère, Introduction au Coran, $2^{\mathrm{e}}$ éd., Paris, 1959, especially p. 79 and following.

23 M. Amari, op. cit., pp. 19-20. 
that it is with regards to some points quite inconsistent. But it is widely used and has become a common reference. On the other hand, a first survey gave me the impression that the five copyists did not completely agree in their way of writing some words. In order to be able to compare their positions in the matter of Qur'anic orthography, I thought it would be better to rely on a set of criteria which would normally be present in most of the contributions and might be later extended to most of the fragments in hija $z \bar{\imath} \bar{l}$ style which have been preserved. Five words seemed to offer a good basis for this comparison: ${ }^{24}$

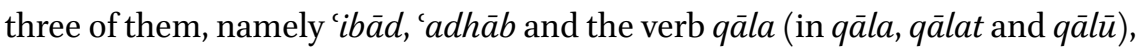
show how the long vowel $|\bar{a}|$ is handled. The other two are also typical of the early written tradition, but in contrast with the former ones where typically an alif is lacking, in words like āyāt (when introduced by a preposition like $b i-$ ) or shay' there may be an additional element which disappeared later. As we have seen, the use of diacritical marks is more difficult to analyse: the evidence of the manuscripts shows that in some instances a copyist will use more dots than in other places, without any obvious reason.

The first word on the list, 'ibäd, is usually written without alif, thus looking like the singular ' $a b d$, except in a few places where Hand A has indicated the long vowel. ${ }^{25}$ The situation is somewhat different in the case of 'adhāb. Hand A contrasts with Hand C, the former using systematically the scriptio defectiva without alif whereas the latter employs the scriptio plena unless he has to write 'adhā $b^{a n}$ - which he writes defectively. Hand B seems to follow the same pattern and Hand E only writes the word once, in the scriptio plena. ${ }^{26}$ The root $Q W L$ is far more commonly found in the Qur'anic text and the variations concern the third person singular (qūla and $q \bar{a} l a t)$ and plural $(q \bar{a} l u) .{ }^{27} Q \bar{a} l a$ is predominantly written in the defective way, with Hand B and E standing apart, the former with three instances of scriptio plena of $q \bar{a} l a$ and the latter with two. As for $q \bar{a} l u$, the only exception is in the contribution of Hand B. Surprisingly, the less frequent qälat is written with the alif thrice by Hand A, the other twenty-one instances being all in the scriptio defectiva.

The plural $\bar{a} y \bar{a} t$ exhibits a peculiarity when it is preceded by a prefix like $b i$, as in bi-âa $\bar{a} t i n \bar{a} .{ }^{28}$ In contrast with the plural $\bar{a} y \bar{a} t$ which is written alif, then a denticle for $y \vec{a}$ and the final $t \bar{a}$, an extra denticle is consistently added by

\footnotetext{
24 F. Déroche, op. cit. (2009), pp. 54-56.

25 Ibid., p. 55 .

26 Ibid.

27 Ibid., pp. $55^{-56}$.

28 Ibid., p. 54.
} 
the three copyists who had to transcribe the word, Hands A, B and C (the other two, Hands D and E did not encounter it in the short portion of text they were entrusted with), with three exceptions due to Hands A and B. Conversely, there is a case where the word is written with three denticles without being preceded by a prefix. The extra letter, in the shape of a $y \vec{a}$ (although the copyists do not dot it as such), indicates a long vowel. This specific way of noting an $/ \bar{a} /$ may be due to the presence of $b i$ - that engendered a phenomenon of vowel harmony -imāla of the $|\bar{a}|$. When it is not in the indeterminate direct case (shay'an), shay' is written with an alif between the shin and the $y \bar{a}^{3}$ by Hands A, D and E. ${ }^{29}$ Hand $\mathrm{C}$ uses the canonical orthography ${ }^{30}$ and $\mathrm{B}$ hesitates between the two, writing the word like Hand A in six occasions and twice like Hand C.

It turns out that the copyists do not share the same stand about the orthography. As can be seen from the preceding remarks, the individual positions are rather coherent. They are not the consequence of variations found on the exemplar since this would entail that the changes of hands were adjusted on its orthographic variations: the copyists would have had to detect the variations and adapt their script in a such careful way that the end of each contribution would contain no trace of compression or expansion of the script in order to adapt to the space left on the page before giving way to the next copyist. Hands A and C, the two main contributors to the transcription of the Codex Parisino-petropolitanus, disagree on the orthography of shay' and 'adhāb, the latter opting for the scriptio plena (in this case considering under this heading the canonical orthography of shay'). Hand B appears somewhat hesitant between $\mathrm{A}$ and $\mathrm{C}$, although he can be said to be closer to the former than to the latter. As for the last two copyists, their share of work is too limited to be able to draw a final conclusion. Hand E, however, also seems unsure about the correct orthography, using both scriptio defectiva and scriptio plena in his contribution. In any case, the hesitancy which can be detected in the portions of text transcribed by Hands A, B and E points to the fact that the orthography was to some extent a matter of individual - and autonomousdecision.

The defective way in which the long $\mid \bar{a} /$ is written is certainly the most obvious feature of the manuscript. In some cases—as is the case with bi-ayant-, the

29 Ibid., pp. 54-55.

30 This orthography appears on the mosaic inscription of the Dome of the Rock, thus dated 72/691 (see C. Kessler, Abd al-Malik's inscription in the Dome of the Rock: a reconsideration, JRAS 1970, n. 21; O. Grabar, The shape of the Holy, Early Islamic Jerusalem, New York, 1996, fig. 42). 
handwritten tradition provides some information about the oral transmission. The most striking example of the use of a denticle which has probably to be understood as a $y \bar{a}$ is that of $i \bar{a} h$ written alif /läm/denticle/hă in $7: 158$ which is graphically identical with ilayhi. ${ }^{31}$ Conversely, the personal name Ibrähim is most of the time written without a denticle between $h \bar{a}$ and $m \bar{\imath} m$, as is usually the case in the canonical version-except in sura 2 . Since the $|\bar{l}|$ is consistently rendered in the Codex Parisino-petropolitanus, it may point to a scriptio defectiva of $|\bar{a}|$, hence to a situation similar to that of iläh. Very puzzling is the treatment of words like Qur'ān or jabbār: the alif is no longer written when the word is in the indefinite form of the direct case $\left(\operatorname{Qur}^{3}[\bar{a}] n^{a n}\right.$ or $\left.j a b b[\bar{a}] r^{a n}\right) .{ }^{32}$ As for the pair Qur'ān-Qur' $[\bar{a}] n^{a n}$, one may wonder whether the alif indicates the presence of an $|\bar{a}|$ or of a hamza - hence possibly coinciding with a spoken version of that time.

The alif has actually other functions in the script than that of mater lectionis. As alif al-wiqayya, it is part of the ending of the third person plural in the past tense. In the manuscript however, verbs with a defective root like ra'a or naha are written in this case without the alif after the $w \bar{a} w .{ }^{33}$ However, Hand A and $\mathrm{C}$ write the ending of the second and third persons of the jussive plural of ra'a with an alif al-wiqāya, but Hand B hesitates and writes this verbal form sometimes without it. In 7:146 and 148, he actually transcribed it four times from the original, without the alifal-wiqāya. He then encountered in 7:149 the past tense $r a^{\prime} \bar{u}$ which he wrote as it appears everywhere in the manuscript, without the final alif. He must have then realised that he had missed a step in his work and corrected the jussive he had written, adding the smaller alif in the same ink and almost the same ductus. ${ }^{34}$ One should finally note the specific way in which $d h \bar{u}$ is usually written: $d h \bar{a} l / w \bar{a} w /$ alif $! 35$

The alif is also used to indicate the hamza, although on this point again the Codex Parisino-petropolitanus exhibits some peculiarities. ${ }^{36}$ Tradition tells us that at the beginning of the seventh century there were some variations within Arabia on this issue and that in Mecca it was no longer in use. The script has no sign to note it, but a study of the rasm shows that the copyists were sometimes trying to indicate its presence in a word. For this reason, a variety of situations

\begin{tabular}{ll}
\hline 31 & Ibid., p. 6o. \\
32 & Ibid., p. 31 and 70. \\
33 & Ibid., p. 65. \\
34 & Ibid. \\
35 & Ibid., pp. 65-66. \\
36 & Ibid., pp. 66-71.
\end{tabular}


occur in the manuscript. When the hamza is marked by a wāw or a $y \bar{a}$, there are very few discrepancies between the manuscript and the Cairo edition whereas the use of the alif is subject to many variations. When a hamza occurs after an $|\bar{a}|$ and its vowel is a damma or a kasra as in abäuna, the copyists tried to indicate it with a $w \bar{a} w$ or a $y \bar{a}$, but the $|\bar{a}|$ does not appear in the rasm. However, in some cases the copyists seem to have favoured the notation of $|\bar{a}|$ : Hand A writes $j a z a^{2}$ with a final $w \bar{a} w$ when the word is in the subject case, as in 5: 29 and 33, but leaves it aside when the word is suffixed in 3: 87 or 4: $93 .{ }^{37}$ When the hamza is associated with a sukūn, the copyists usually failed in indicating its presence in the text. As a final note in this recapitulation of the treatment of the hamza, it should be noted that in a very few cases an alif is used as a support instead of a wāw (24: 22) or a $y \bar{a}^{3}$ (12: 100) in the Cairo edition. ${ }^{38}$

A verb like qāla, mostly written in scriptio defectiva, contrasts with kāna which only appears in scriptio plena, with a possibly unique exception in 6: 88. Here, in the portion transcribed by Hand E, a crude correction has changed $k(\bar{a}) n \bar{u}$ by addition of an alif into the scriptio plena. This is the only case in the Codex Parisino-petropolitanus where the copyist used what is known to us as the early orthography of the verb. ${ }^{39}$ This case may provide us with an indication about the model from which the manuscript was transcribed, that is to say an original in a more defective orthography. On the other hand, there seems to be a custom in writing defectively in the indefinite form of the direct case, words like shay' or Qur'an. Should we speak of rules? Two forms, $f a^{\text {“ }} \bar{a} l$ and $f u$ ' $l \bar{a} n$, which are sufficiently common as to provide material for a study in this direction, show a contrasting situation: in the Codex Parisino-petropolitanus, fuclann is treated quite coherently in spite of the change of copyists, whereas the $f a^{\text {c }} \bar{a} l$ words exhibit hesitations between the scriptio plena and defectiva - as is the case with the word qahhär, written defectively in 14: 48, but in scriptio plena in 13: 16 and 39: 4 for instance. ${ }^{40}$

The study of the orthography underlines the highly personal approach of the text by the five copyists. A comparison with the Cairo edition allows us to pinpoint the divergences and to suggest an explanation based on the assumption that the written transmission did not undergo major textual changes. It leads to the conclusion that many problems, for instance that of the hamza, had not

\footnotetext{
$37 \quad$ Ibid., p. 68.

38 Ibid., p. 69.

$39 \quad$ Ibid., p. 71 and n. 59.

40 Ibid., pp. 71-74.
} 
been resolved yet and that the relationship of the copyists with the original was not one of subservience, but that they were enhancing the rasm according to their own views while transcribing it. As it cannot be concluded from the manuscript that the changes of hand were dictated either by orthographic discrepancies or by changes of hands in the original, we are led to surmise that the scribes were upgrading the orthography while copying the text. There were however some habits - the term "rules" would be unwarranted-which were common to the group. It is all the more surprising that, given the effort made in making the rasm more intelligible, the copyists did not use the diacritical marks - a graphic tool they knew - in a more coherent way, which would have greatly helped the reader in deciphering the text.

One of the striking features of the Codex Parisino-petropolitanus is the attention paid by the five copyists to the indication of verse endings - with the relative exception of Hand $\mathrm{C}$ who sometimes forgot to mark these divisions. In sharp contrast to the diacritical marks which they sparingly used in order to distinguish homographs, four to six dashes grouped in two columns are carefully repeated in order to separate the verses. These devices are different from those which are found in contemporary documents and take the shape of circles which are quicker to draw than the clusters of dashes favoured by the copyists of Quran manuscripts which stayed however in use for some time. ${ }^{41}$

The verse division itself needs to be more closely analysed. The comparison with the canonical position of the various reading schools as summarised by Anton Spitaler substantiates the specificity of the Codex Parisino-petropolitanus within the Qur'anic tradition. ${ }^{42}$ A first point has to do with the basmala which the latter does not consider as a verse-except in the Fatiha. Two of the copyists, C and D, agree with the tradition, but Hand A indicated in a systematic way a verse ending after the basmala. This first observation points in the same direction as the orthography: the various copyists acted independently of each other and did not share a common stance about the text.

Looking at the other points of the text, one notes that the Codex Parisinopetropolitanus sometimes indicates a verse ending in a place which is not recognised as such by the tradition. This happens for instance in sura 4 where a division was indicated after sabïlan within verse 34 and after $r a s \bar{u} l^{a n}$ within

\footnotetext{
41 See for instance A. Grohmann, From the world of Arabic papyri, Cairo, 1952, pp. 91-93.

42 A. Spitaler, Die Verszählung des Koran nach islamischer Überlieferung, Munich, 1935 [Sitzungsberichte der Bayerischen Akademie der Wissenschaften, Phil.-historische Abteilung. Jahrgang 1935, Heft 11].
} 
verse $79 .{ }^{43}$ In both cases, a later hand scrapped away the mark. Conversely, it does not always consider the same points of the text as verse endings as are otherwise unanimously known as such. For example, in the same sura, no verse ending is found at 4: $71 .{ }^{44}$ Such cases may already be an indication that the manuscript is at variance with the canonical tradition. I shall return to this point later.

Turning now to the five to eight qirāa $\bar{a} t$ systems recorded by Spitaler, I shall study the position of the manuscript in comparison with these various schools in order to identify the school which is followed in the Codex Parisinopetropolitanus. ${ }^{45}$ In principle, the latter should be in complete accordance with one of them, a situation which can be verified by looking at the places where the schools are at a variance, since they disagree on some verse endings as well as, consequently, on the number of verses in the Qur'an.

In the manuscript, ninety-three cases about which some schools have a specific stance are present. Only thirty-eight of those are common with the Kufan school, which clearly excludes any relationship between its reading and that of the Codex Parisino-petropolitanus. Conversely, the latter mostly agrees with the Homs reading, in seventy-five cases of the disputed verse endings. ${ }^{46}$ It is therefore possible to state that it is verging towards this specific school, although it cannot be said to reflect its position as a whole. In many instances, a verse ending which is only known in the Homs tradition is indicated in the manuscript. For example, the latter indicates within 9: 36 after al-din al-qayyim the end of a verse which is only known by this school. ${ }^{47} \mathrm{On}$ the other hand, there are cases where a typically Himsi verse division is not present in the manuscript. In 28: 38 , for instance, the Himsi school considers that there is a verse ending after 'ala al-tịn, but there is no mark at that place in the manuscript. ${ }^{48}$ Conversely, a division at $24: 44$, common to all the schools except that of Homs, was marked by Hand A. ${ }^{49}$

The beginning of sura 3 deserves attention. ${ }^{50}$ The copyist disagrees with the Kufan school, which has a division after alif-lām-mìm (its verse 1) but not after

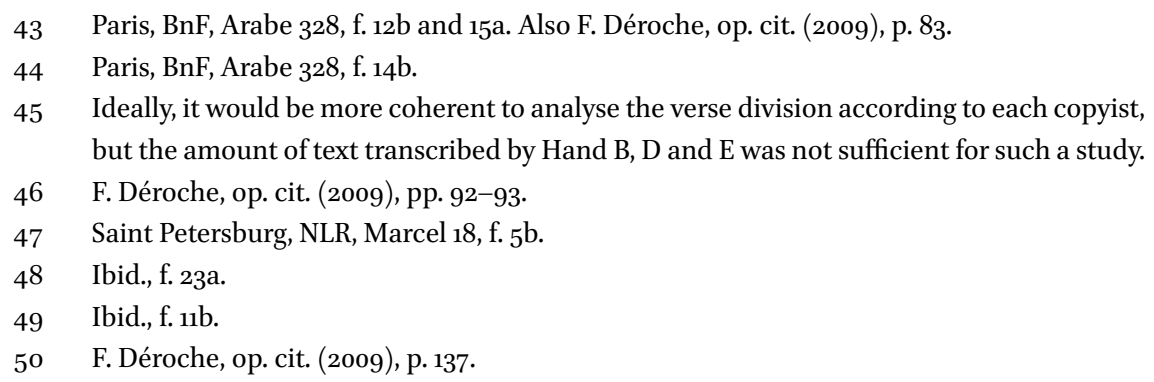


al-furqān, but follows on both points the other schools. He disagrees with all the schools since he considers the basmala as a verse, but does not stop after al-qayyūm (verse 2 in the Kufan tradition), nor after $f \grave{\iota}$ al-sama $\bar{a}$ (verse 5 ). He then agrees with the Syrian tradition (Damascus and Homs) in disregarding the division at $3: 3$. The next verse about which there is a general agreement is verse 6: it has the same number in other schools, but not in the Syrian tradition which sees it as verse 5. As for the Codex Parisino-petropolitanus, it is its verse 4-counting the basmala as a verse.

To sum up, the Codex Parisino-petropolitanus does not indicate a verse ending in twelve places which Spitaler's tables record as unanimously considered as such by the tradition. ${ }^{51}$ Conversely, it indicates within seven verses a division which is not recorded by the tradition. ${ }^{52}$ The verse ending within $5: 3$ after bi-l-azläm stands alone within this group as it defines a rather long textual sequence whereas the other ones are quite short. It coincides with a change of meaning which has been recognised by Friedrich Schwally and Richard Bell and the verse thus divided - which is seen by some authorities as the last revealed verse-would receive a specific identity. ${ }^{53}$

The six other divisions specific to the Codex Parisino-petropolitanus share a common feature: the portion of text comprised between them and the next verse ending is a short textual unit which in all cases except 25: 4 can be defined as a very general enunciation ending with a word rhyming with the neighbouring verses. In 4: 79, shahìd ${ }^{a n}$ rhymes with fatïlan, hadīth ${ }^{a n}$, hafiz ${ }^{a n}$ and wakilan, a sequence interrupted in the Codex Parisino-petropolitanus by the verse ending rasülan which is only recorded in this copy. ${ }^{54}$ In 9: 115, 'alim echoes the endings in $-\bar{\imath} m$ and $-\bar{\imath} r$, but yattaqūn, which corresponds to the division found in the manuscript, disrupts the sequence. ${ }^{55}$ The $-\bar{a} r$ sequence of rhymes at the beginning of sura 14 is interrupted by the word al-zälamin which the manuscript considers as the last word of a verse. ${ }^{56}$ The only partial exception to this is the short segment within $25: 4$ which reads: "So they [= the

\footnotetext{
$5^{1} \quad$ Ibid., pp. 93-94.

52 Ibid., p. 93 .

53 Ibid., p. 141. See F. Schwally, Geschichte des Qorâns, 2nd ed., Leipzig, 1909, vol. I, p. 227; R. Bell, The Qur'ân. Translated, with a critical re-arrangement of the Surahs by Richard Bell, t. I, Edinburgh, 1937, pp. 93-94.

54 F. Déroche, op. cit., p. 138. Further examination of the copies in hijāzī style may unearth other examples of a division at this specific place or at the points analysed here.

55 Ibid.

$56 \quad$ Ibid.
} 
misbelievers] have committed wrong and falsehood"; 57 as it appears today in the Qur'anic text, it is inserted between two elements conveying the words of the misbelievers, "The unbelievers say: This is naught but a calumny he has forged, and other folk have helped him to it" (beginning of 25:4) and "And they say: Fairy tales of the ancients that he has had written down, so that they are recited to him at dawn and in the evening" $(25: 5) \cdot{ }^{58}$ In this case, the short segment of 25: 4 which appears as a verse in the Codex Parisino-petropolitanus provides a rhyme to 25:3 (nushū ${ }^{a n}$ and wazūran) and more generally to the beginning of the sura $\left(-i C^{a n}\right)$ which is not the case of akharün, the verse ending specific to the manuscript within 25: 4. It is also a strong rebuttal of the accusations levelled against Muhammad by his enemies.

How should we understand this peculiarity of the Codex Parisino-petropolitanus? I suggest that the "short verses" are the trace of an editing of the text which took place when the revelations were put together in larger portions of text. In these cases, a verse which was not rhyming with the surrounding verses was complemented by a short sentence which solved the problem of the rhyme. The hypothesis of such an editorial work was first formulated by Schwally, ${ }^{59}$ then by Bell. ${ }^{60}$ The tradition preserved an account which to some extent is similar to what has been found here: a scribe of the revelation was said to have uttered an exclamation as Muhammad was completing the dictation of a verse; and the prophet would have taken over the words and had them added to the text. ${ }^{61}$ The scribes in charge of the final transcription of the revelations may have unintentionally left some marks of this editorial work which survived during a short period of time until the canonisation process was over.

According to Muslim tradition, the caliph 'Uthmān had some copies of the text transcribed once the recension he had ordered was completed. ${ }^{62} \mathrm{He}$ sent

57 Ibid., pp. 140-141.

$5^{8}$ Translation by Arthur A. Arberry (The Koran interpreted, New York, 1955, vol. 2, p. 56).

59 F. Schwally, op. cit., p. 41.

6o W.M. Watt and R. Bell, Introduction to the Qur'an, Edinburgh, 1977, pp. 90-93 (especially pp. 92-93). See also A.T. Welch, s.v. “Kur’ān”, $E I^{2}$, vol. 5, p. 422.

61 See F. Schwally, op. cit., pp. 46-47.

62 See al-Dānī, K. al-Muqni' fì márifa marsūm mașāhif ahl al-amṣār, ed. M.A. Dahmān, s.d., p. 9, l. 8-11 (ed. Pretzl, Istanbul, 1932, p. 10), who mentions four copies; he then goes on with another account mentioning seven copies (ibid., l. 11-13). Al-Dānī obviously supports the first version. The question of the stemma which would explain these differences had been addressed by T. Nöldeke (op. cit., p. 242), then by G. Bergsträsser and O. Pretzl (Geschichte 
them to the main cities of his empire. But they were not completely identical and contained a few peculiarities. In his study of the Parisian part of he Codex Parisino-petropolitanus, Yasin Dutton demonstrated that the variants found in the manuscript were those of the copy which, according to the tradition, was sent to Damascus. ${ }^{63}$ It follows the Syrian reading of Ibn 'Āmir. At 3: 184, for instance, it reads bi-z-zubur instead of az-zubur in all the other readings. The portion of the manuscript kept in Saint Petersburg does not alter this picture: among the variants which are recorded for this part of the text, only one in 57 : 10 is specific to Ibn 'Amir's reading. ${ }^{64}$ Dutton's conclusions are thus confirmed.

In addition to these canonical variants, the copy contains small variants which I shall briefly analyse. Some cases are clearly the result of a scribal mistake, some of which were actually corrected by the copyists themselves. ${ }^{65}$ The upper part of the f. $18 \mathrm{~b}$ in the Parisian part of the Codex Parisino-petropolitanus has been carefully erased by the same copyist who probably realised that what he had transcribed was faulty and the correct version was written over. ${ }^{66}$ In the portion of the Qur'an which was transcribed by Hand C, there seems to be a higher frequency of scribal mistakes. ${ }^{67}$ Other situations are not so easy to characterise: in 3: 189 for instance, the original text can be read as wa-Alläh malik as-samawāt wa-l-ard which was later corrected into the canonical wa-li-Lläh mulkas-samawät by erasure of the alif. ${ }^{68}$ In many places, as in the former example, the erasure did not eliminate completely the original text and it is possible to decipher it, but in other cases it has been quite effective.

Once the obvious scribal mistakes like the dittographies in 42:14 and 24 have been eliminated, ${ }^{69}$ there remain about ten cases which cannot be satisfactorily explained as a peculiarity of the early Qur'anic orthography or as an error. In the majority of the cases, the variants consist of an additional coordinating

des Qorâns, 2nd ed., vol. III, Leipzig, 1938, p. 15). For a recent approach, see M. Cook, The stemma of the regional codices of the Koran, in Graeco-arabica. Festschrift in honour of V. Christides, G.K. Livadas ed., vol. 9-10, Athens, 2004, pp. 89-104.

63 Y.Dutton, An early muṣhaf according to the reading of Ibn 'Āmir,Journal of Qur'anic studies 3 (2001), pp. 71-74.

64 F. Déroche, op. cit. (2009), pp. 104-105.

65 Ibid., pp. 45-46.

66 F. Déroche, op. cit. (2009), p. 105.

67 Ibid., pp. 45-46 and 107.

68 Ibid., p. 105 (Paris, BnF, Arabe 328, f. ga).

69 Ibid., p. 106. 
conjunction, as in 5:12 or 7:14 for instance. ${ }^{70}$ In all these cases, the erasure of the supplementary element ensured the conformity of the manuscript with the canonical rasm. Conversely, in 10: 37, a missing wāw has been added at the beginning of the verse. ${ }^{71}$ The original wa-laha in 4: 12 has been changed into wa-lahu, the only element which can still be deciphered in a verse which has been carefully emended. ${ }^{2}$ Other variants were not corrected. In 11: 31 , the Codex Parisino-petropolitanus reads li-lladhi instead of li-lladhina and $y \bar{a}$ laytanī instead of laytanī in $25: 28 . .^{73}$

Non-canonical variants similar to those found in the manuscript are also observed in contemporary fragments or manuscripts-according to their script. In all of them, the text conforms basically to the 'Uthmanic rasm, with canonical variants as well as others corresponding to the same typology as those of the Codex Parisino-petropolitanus I previously mentioned. An analysis of the situation of the variants during the second/eighth and early third/ninth centuries shows that the compilation and canonisation of their lists is comparatively late and probably based on later copies. The text found in the early copies may therefore reflect a state of the Qur'an's transmission predating the work of the scholars of the second/eighth and third/ninth centuries and may still have been somewhat fluid. ${ }^{74}$ The same holds for the division into verses, which had not yet undergone the systematisation corresponding to the canonical lists concerning the number of verses, the earliest of which are dated to the end of the second/eighth century. It also applies to the basmala considered a verse by some of the copyists—-such as A.

The scribal mistakes, like one at the beginning of 3: 129, but also the possible variant at the beginning of $3: 189,{ }^{75}$ both initially with Allāh instead of the canonical li-Lläh, provide us with a precious hint about the circumstances under which the copyists worked. The clear difference between Alläh and li-Lläh excludes that they may have been transcribing the text by memory or by dictation, since such a confusion would not be possible. Another indication in that direction are the instances in the text, like 6:88, 7:146 and 7:148, where

$70 \quad$ Ibid., pp. 106-107.

71 Ibid., p. 107.

72 Ibid. See also D. Powers, Muhammad is not the father of any of your men. The making of the last prophet, Philadelphia, 2009, ch. 8 (pp. 155-196) about 4: 12 in Arabe 328.

73 Ibid.

74 I. Rabb aptly introduced the concept of "fluidity" in her paper about London, BL Or. 2165 (Non-Canonical Readings of the Qurān: Recognition and Authenticity (The Himsī Reading), Journal of Qur'anic Studies, vol. 8, no. 2, 2006, p. 108). 
the orthography was upgraded by the copyists. ${ }^{76}$ The last two instances are especially telling as the addition of the four alifal-wiqaya by Hand B cannot be due to a repeated omission of that letter but rather to a faithful transcription of the defective original by a copyist momentarily oblivious of his task and correcting himself once he had discovered his mistake. All these instances point in the same direction: the Codex Parisino-petropolitanus was transcribed from an older exemplar written in a more defective orthography that the five scribes were trying to improve while they were copying.

The Codex Parisino-petropolitanus was certainly quickly superseded by copies which were more accurate as far as the orthography, the use of diacritics or of vocalisation are concerned, and more pleasing to the eye both in terms of the quality of the script and the presence of illuminations. However, the manuscript contains many indications that it remained in use for a comparatively long period of time. This appears first when one looks at the division into verses and groups of verses. ${ }^{77}$ Some of the original marks were eliminated: it is no wonder that the seven non-canonical verse endings were erased, but such was also the fate of other divisions which were either common to all the schools, like 3: 122 and 8: $62,{ }^{78}$ or proper to some of them-for instance 4: 44 or 14: $24 .{ }^{79}$ Conversely, some of the canonical verse endings which were absent in the manuscript were added by later hands, at $3: 2$ and 5 or 23: 112 for example. ${ }^{80}$

Indications of groups of five and ten verses were also introduced at some moment. ${ }^{81}$ The former were signalled by the addition of a red alif surrounded by dots in the same colour. The latter were highlighted by a red circle drawn after erasing the original verse ending. Both were probably the work of the same person who apparently did not complete his work as he stopped at f. $64 \mathrm{~b}$ of the Parisian portion of the manuscript. These marks were later enhanced by the addition of alphabetic numerals (abjad); but in some cases, the red circles have been erased and the tenth indication has been written in another place. The previous indications at 14:30 and 40 have for instance been superseded by those with a lām (value: 30 ) at 14: 28 and with a mim (value: 40) at 14: $38 .{ }^{82}$

$\begin{array}{ll}76 & \text { Ibid., p. 153. } \\ 77 & \text { Ibid., pp. 94-101. } \\ 78 & \text { Ibid., p. 8o. } \\ 79 & \text { Ibid. } \\ 80 & \text { Ibid., p. 94. } \\ 81 & \text { Ibid., pp. 94-95. } \\ 82 & \text { Ibid., p. 95. }\end{array}$


In this case, the work has been carried out until the end of what has been preserved. On palaeographical grounds, it is possible to date this numeration prior to the fourth/tenth century, probably to the third/ninth century. This date is also suggested by the fact that it does not agree with the canonical systems which were introduced by the turn of the century.

The analysis of these additions shows that the marks of ten do not always agree with the original verse endings as far as the total number of verses in a sura is concerned. When the observation is possible, it becomes clear for instance that the person who added the abjad marks did not consider the basmala as a verse. ${ }^{83}$ In other places of the text, the situation looks more complicated since in some cases he took into account the original division but in others he did not, although he paid no attention to the verses that were not canonical. ${ }^{84}$

The text itself was also modified by later readers. The erasures which we see today may have been made by the copyists themselves, but also by later users. When no correction has been added afterwards, it is difficult to decide who was responsible for it. ${ }^{85}$ In other cases, the answer is more obvious, as is the case in the last line of $\mathrm{f} .3 \mathrm{ob}$ of the Parisian part of the manuscript. ${ }^{86}$ The script belongs to one of the later styles in use in Abbasid times, close to the B group-according to the palaeographical typology I have put forward ${ }^{87}$ It could be dated to the third/ninth century. Another hand seems slightly later: he modified the text in various places, using a black ink quite different from that of the previous correction. The style can be defined as NS, thus pointing to a date at the end of the third/ninth or beginning of the fourth/tenth century. ${ }^{88}$ Most of the time, this corrector contented himself with rewriting faithfully the original text, probably in order to make it more legible. To these two stages of correction has to be added the somewhat crude attempts at re-inking the faded letters especially on the hair sides of the parchment, trying to follow the original characters. ${ }^{89}$ They are unfortunately very difficult to date.

All these various later interventions suggest that the community where the Codex Parisino-petropolitanus was kept viewed it as sufficiently important as to

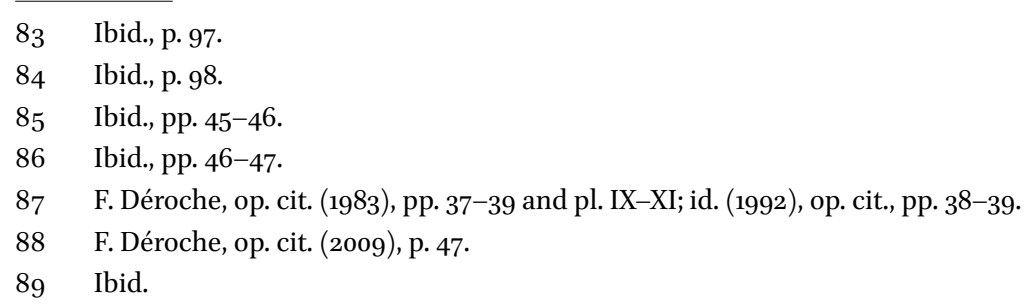


justify changes which were aimed on the one hand at keeping it legible and on the other at adjusting its presentation of the text in order to bring it closer to the canonical version and to more recent standards.

When and where was the Codex Parisino-petropolitanus transcribed? As we have seen, the text of the Fihrist suggests that the hijäzi style was among the earliest varieties of Arabic script. On the other hand, being a copy of an earlier codex, it can hardly be dated before the middle of the first/seventh century, the more so because the copyists are adjusting the orthography in order to note more precisely the Quranic text. The highly idiosyncratic way in which the five copyists worked suggests on the other hand that the reforms of 'Abd al-Malik (who reigned from $65 / 685$ to $86 / 705$ ) had not yet been enforced. It should however be noted that Hand D writes in a very regular way, almost professional. If we accept the information provided by the Muslim tradition about the intervention of the Umayyad governor of Kufa, the famous al-Hajjāj b. Yūsuf and what Omar Hamdan called the "Mașăhif project", ${ }^{90}$ we have to note that some of its features lack entirely in the manuscript. The manuscript could therefore be attributed to the third quarter of the first century AH, between 671 and $695 \mathrm{AD} .{ }^{91}$ It would thus be one of the earliest witnesses of book production in Umayyad times.

The place of copy of the manuscript eludes us. On the basis of the canonical variants present in the Codex Parisino-petropolitanus, Dutton suggested Syria as the possible origin of this copy. ${ }^{92}$ However, the lack of information about the diffusion of the readings at an early date calls for caution. The place where it was kept until the beginning of the nineteenth century, the 'Amr mosque in Fustat, leaves open the possibility that it was transcribed there. But it may also have been brought in from another place, as other manuscripts found in this trove.

Western scholars have described the text of the Codex Parisino-petropolitanus as Qur'anic and this was already the opinion of the corrector who, by

$90 \quad$ O. Hamdan, Studien zur Kanonisierung des Korantextes. Al-Hasan al-Basris Beiträge zur Geschichte des Korans, Wiesbaden, 2006, pp. 135-174.

91 M. Tillier suggested to identify the Codex Parisino-petropolitanus with the muṣhaf of Asmä' (review of F. Déroche, La transmission écrite du Coran dans les débuts de l'islam. Le codex Parisino-petropolitanus, [Texts and studies on the Qur'ān 5] Leiden-Boston, 2009, Journal of Qur'anic Studies 2011, pp. 112-114). The script and the lack of features described as part of the "Mașāhịf project" of al-Hajjāj (see O. Hamdan, op. cit., pp. 135-174) are two strong arguments against this identification.

Y. Dutton, op. cit., p. 83 . 
the end of the ninth century wrote the name of the suras in red. But does it fit the traditional history of the writing down of the Qur'an? According to these accounts, the Muslim commander of the troops during a campaign in Armenia (around 650) heard that his soldiers were reciting the Qur'an in very different ways. ${ }^{93}$ Shocked, he came to report to the caliph 'Uthmān (who reigned from 644 to 656 ) and begged him to take steps in order to avoid that Muslims would experience the same situation as Jews and Christians who were quarrelling over their scriptures. 'Uthmān then ordered to make a recension which would prevent that. When looking at the transcription of the Codex Parisino-petropolitanus, one sees that this copy as well as all those which belong to these chronological strata of the transmission are unable to prevent what the 'Uthmanic edition was supposed to achieve. With very few diacritics, no short vowels or orthoepic marks, it simply could not have provided the solution which the caliph is said to have been seeking according to the Muslim tradition. In addition, the small non-canonical variants and the peculiarities of the division of the text into verses suggest that at the time when the manuscript was transcribed, the rasm was not yet fully fixed, although the Codex Parisinopetropolitanus is in itself proof that the part of the canonical text corresponding to the contents of the manuscript was there-more precisely: is compatible with them. Is the manuscript unique of its kind? A more general appraisal of the transmission of the Quranic text in copies in hijāzž style will help us answer this question.

93 Al-Bukhārī, Șahịh, ed. 'A.'A. B. Baz, Beirut, 1994, vol. I, p. 66. 